\title{
A GIS-based logistic regression model in rock-fall susceptibility mapping along a mountainous road: Salavat Abad case study, Kurdistan, Iran
}

\author{
Ataollah Shirzadi $\cdot$ Lee Saro $\cdot$ Oh Hyun Joo $\cdot$ Kamran Chapi
}

Received: 29 May 2011/ Accepted: 27 July 2012/Published online: 1 September 2012

(C) The Author(s) 2012. This article is published with open access at Springerlink.com

\begin{abstract}
This study describes the application of logistic regression to rock-fall susceptibility mapping along $11 \mathrm{~km}$ of a mountainous road on the Salavat Abad saddle, in southwest Kurdistan, Iran. To determine the factors influencing rock-falls, data layers of slope degree, slope aspect, slope curvature, elevation, distance to road, distance to fault, lithology, and land use were analyzed by logistic regression analysis. The results are shown as rock-fall susceptibility maps. A spatial database, which included 68 sites (34 rock-fall point cells with value of 1 and 34 no rock-fall point cells with value of 0 ) was developed and analyzed using a Geographic Information System, GIS. The results are shown as four classes of rock-fall susceptibility. In this study, distance to fault, lithology, slope curvature, slope degree, and distance to road were found to be the most important factors affecting rock-fall. It was concluded that about $76 \%$ of the study area can be classified as having moderate and high susceptibility classes. Rock-fall point cells were used to verify results of the rock-fall susceptibility map using success curve rate and the area under the curve. The verification results showed that the area under the curve for rock-fall susceptibility map is $77.57 \%$. The results from this study demonstrated that the use of a logistic regression model within a GIS framework is useful and suitable for rock-fall susceptibility mapping. The rock-fall susceptibility map can be used to reduce susceptibility associated with rock-fall.
\end{abstract}

Keywords Rock-fall - Susceptibility map - Logistic regression · Salavat Abad · Kurdistan · Iran

\section{Introduction}

Rock-falls occur when masses of rock or other material detach from a steep slope or cliff and descend by free fall, sliding, toppling, or bouncing. Rock-fall is one of the main slope

\footnotetext{
A. Shirzadi $(\bowtie) \cdot$ K. Chapi

University of Kurdistan, Sanandaj, Kurdistan, Islamic Republic of Iran

e-mail: A.Shirzadi@uok.ac.ir

L. Saro · O. Hyun Joo

Geoscience Information Center, Korea Institute of Geoscience \& Mineral Resources (KIGAM),

92 Gwahang-No, Yuseong-Gu, Daejeon 305-350, Korea
} 
movement processes in the natural evolution of rocky mountain slopes (e.g., Selby 1982). On February 10, 1996, a huge rock-fall along highway 229 on Hokkaido Island in Japan killed 20 people and captured much international attention to the rock-fall problem (e.g., Yamagishi 2000). It has been known that $10 \%$ of world population lives in mountainous terrains and $36 \%$ of the lands are mountainous. With the high increase in world population, human activities in mountainous areas have correspondingly increased (e.g., Chau et al. 2003). The intensified human activities in mountainous terrains have led to land cover change, deforestation, and more livestock grazing on steep slopes, which can trigger huge mass movements (e.g., Kelarestaghi and Ahmadi 2009). On March 2008, rock-falls on the Hezar Cham saddle in northern Iran, which was triggered by earthquakes and heavy precipitations, killed 21 people and caused heavy damages to the road (http://www.ngdir.ir ). On February 14, 2006, a rock-fall on the Gheshm-Maigon road in southern Iran has led to the destruction of 1,000 $\mathrm{m}$ of the road and damaged 5 houses. According to the reports by the Transport Office of the Kurdistan province, in 2006, the total costs of the damages from rock-falls to the Salavat Abad saddle (the case study) were about 28,000\$ (Fig. 1).

Studies of rock-falls are often based on field surveys, and susceptibility is estimated either by an empirical assessment of susceptibility to failure, or by the calculation of a safety factor derived from models of rock mechanics (e.g., Hoek and Bray 1981). Once a location is identified with rock-fall risk, the probability of the maximum travel distance and maximum energy of impact of rock-fall events at the location is normally assessed using computer simulations (e.g., Wu 1985; Kobayashi et al. 1990; Azzoni et al. 1995).

There are many different models for study on rock-fall events in three main categories: (1) empirical models based on relationships between topographical factors and the length of the run out of rock-falls (e.g., Keylock and Domaas 1999), (2) process-based models that describe or simulate the modes of motion of falling rocks over slope surfaces (e.g., Kirkby and Statham 1975; Statham 1976; Hungr and Evans 1988; Pfeiffer and Bowen 1989; Kobayashi et al. 1990), and (3) GIS-based models that are running within a GIS environment or they are raster-based models for which input data are provided by GIS analysis (e.g., Evans and Hungr 1993; Hegg and Kienholz 1995; Chau et al. 2004). Little work was done on rock-fall susceptibility mapping based on GIS (e.g., Carrara et al. 1995; Chung et al. 1995; Guzzetti et al. 1999; Suzen and Doyuran 2004a, b; Chau et al. 2004). Susceptibility maps are found to be very useful in estimating, managing, and mitigating mass movement susceptibility for a region (e.g., Corominas and Santacana 2003; Chung and Fabbri 2003; Sassa et al. 2004).

There are various methods to susceptibility mapping including the following: semiqualitative methods similar to the analytical hierarchy process (AHP) (e.g., Barredol et al. 2000), bivariate statistical analysis (e.g., Kelarestaghi and Ahmadi 2009; Nandi and Shakoor 2009), the probability-frequency ratio model (e.g., Lee and Pradhan 2006), and multivariate regression methods such as logistic regression (e.g., Lee and Sambath 2006; Pradhan 2010; Su and Cui 2010; Choi et al. 2012). The recent and rapid increase in computing capacity has also allowed scientists to treat large sets of data, which is a crucial factor in applying multivariate statistical analysis. Multivariate procedures have long been employed for landslide susceptibility mapping (e.g., Reger 1979; Carrara et al. 1992; Gorseveski et al. 2000; Baeza and Corominas 2001; Lee and Min 2001; Ayenew and Barbieri 2005; Can et al. 2005; Chau and Chan 2005; Greco et al. 2007). Among the various susceptibility mapping methods, logistic regression (LR) presents certain advantages for studying the landslides of soil and/or weathered rocks (e.g., Gorseveski et al. 2000; Dai and Lee 2002; Chau et al. 2004; Ayalew and Yamagishi 2004; Lee and Sambath 2006; Akgun and Bulut 2007; Akgun et al. 2008; Lamelas et al. 2008). Since very few 

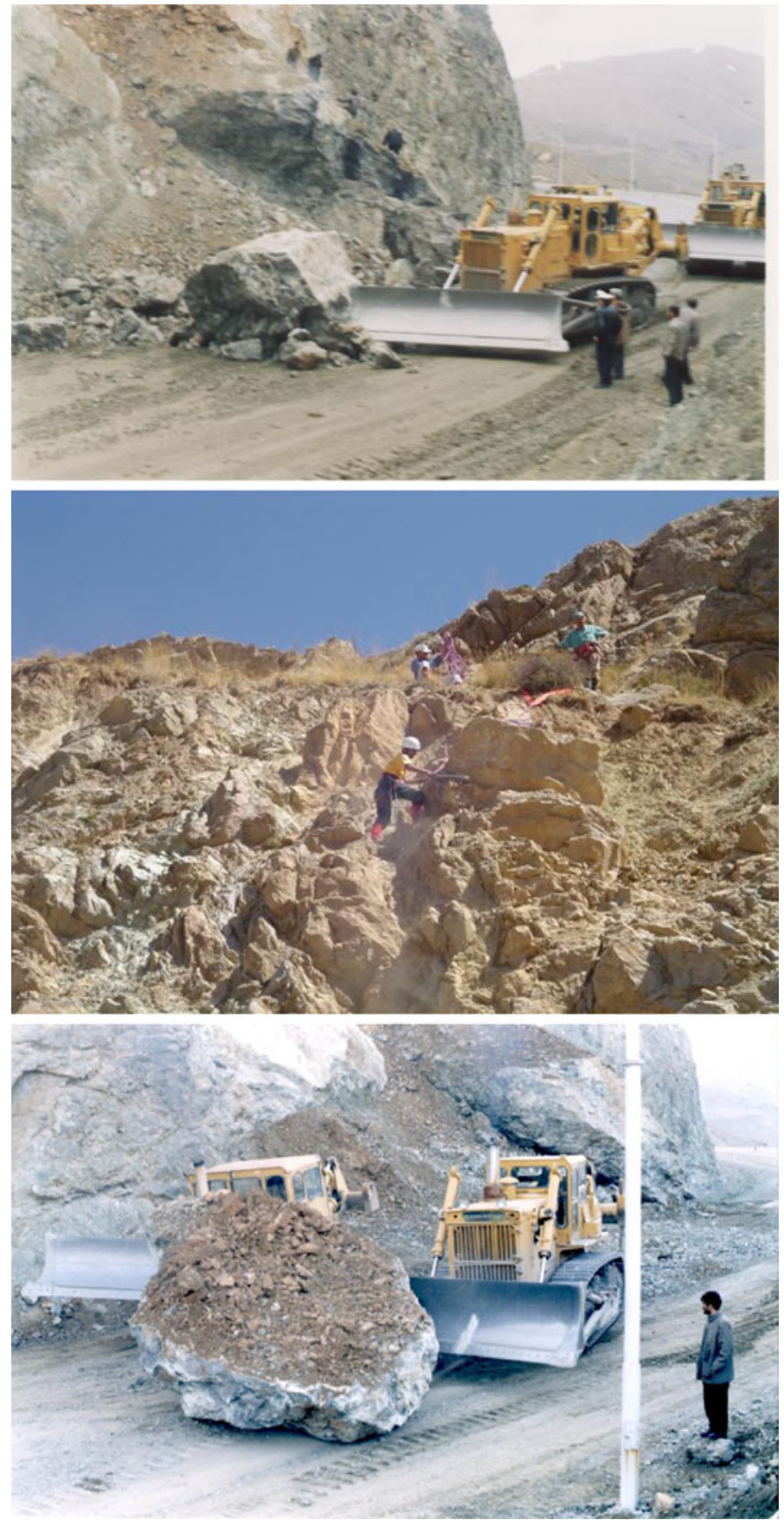

Fig. 1 Rock-falls cleanup on Salavat Abad road at Kurdistan, Iran 
studies on rock-fall susceptibility mapping based on GIS and statistical analysis have been noticed (e.g., Chau et al. 2004); we decided to further study this topic. Thus, the aim of this research is to apply and assess a logistic regression model to generate rock-fall susceptibility map along a mountainous road in the western parts of Iran.

\section{Materials and methods}

\subsection{Topographic and geologic setting of the study area}

The Salavat Abad saddle is located between longitudes of $47^{\circ}, 07^{\prime}, 48^{\prime \prime}$ and $47^{\circ}, 08^{\prime}, 57^{\prime \prime} \mathrm{N}$ and latitudes of $35^{\circ}, 15^{\prime}, 16^{\prime \prime}$ and $35^{\circ}, 19^{\prime}, 40^{\prime \prime} \mathrm{E}$, in the southwest parts of the Kurdistan province, Iran (Fig. 2). It covers an area of about 1871 hectares. The elevation is varying from 1,699 to $2,500 \mathrm{~m}$ above sea level. The study area selected is a part of the Zagros Mountainous region, whose geologic setting resulted from tectonic activities at the end of tertiary period. The Salavat Abad saddle is the effect of internal tectonization by orogen on the Zagros Mountains. Geology units in the study area include the following: North-South trending andesitic and basaltic rocks, limestone and red conglomerates (Fig. 3). The main lithology is the limestone occupying nearly $94 \%$ of the study area. The Salavat Abad saddle has an $\mathrm{N}-\mathrm{S}$ trend and is thrust over volcanic deposits. The limestone in the study area has been affected by mechanical weathering, snow melt, and frequent freezing so that several rock-falls have taken place at the section of this road.

One step in generating a rock-fall distribution map was taken in the laboratory, and another one was taken in the field. Recognition of rock-falls on aerial photographs is difficult because they are located on steep slopes and artificial slopes and easily confused with man-made objects. Thus, they are not easily identified similarly to the landslides that have occurred at a scale larger than that of the falls. Therefore, the recognition of rock-falls in the study was done directly in the field. The collection of the rock-falls locations was recorded by the Transport Office of the Kurdistan province in 2006. Based on the discontinuity in the rock-falls, the geologists at the Transport Office of the Kurdistan province have recorded the central of each rock-fall slopes as one of the 34 rock-falls in the study area. When the 34 rock-falls were selected, 50 no-rock-falls locations were recorded by the same method as the 34 rock-falls were selected. Finally, 34 out of 50 no-rock-falls were

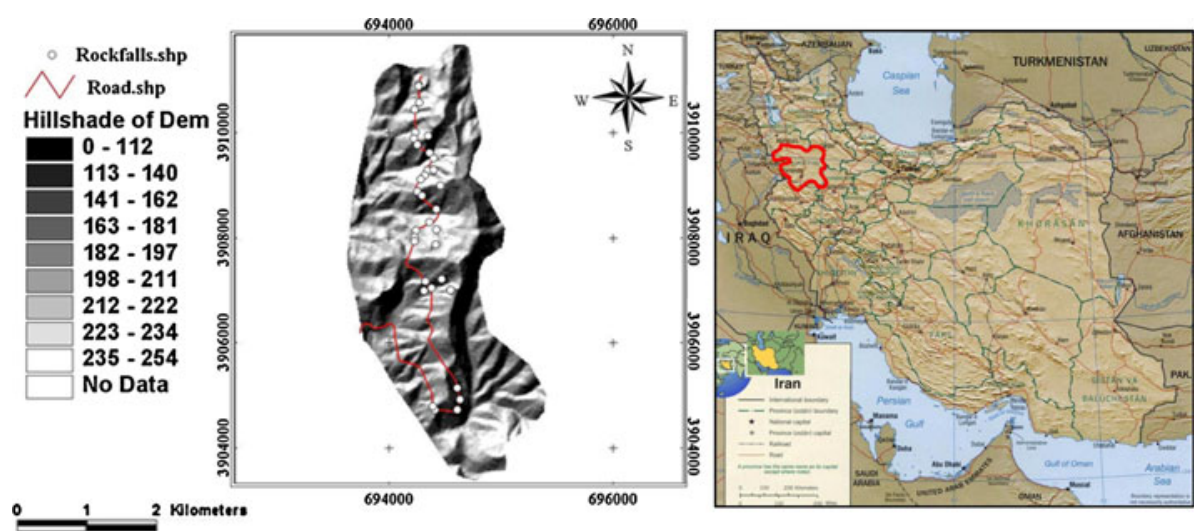

Fig. 2 Location of rock-falls in the study area and Iran 


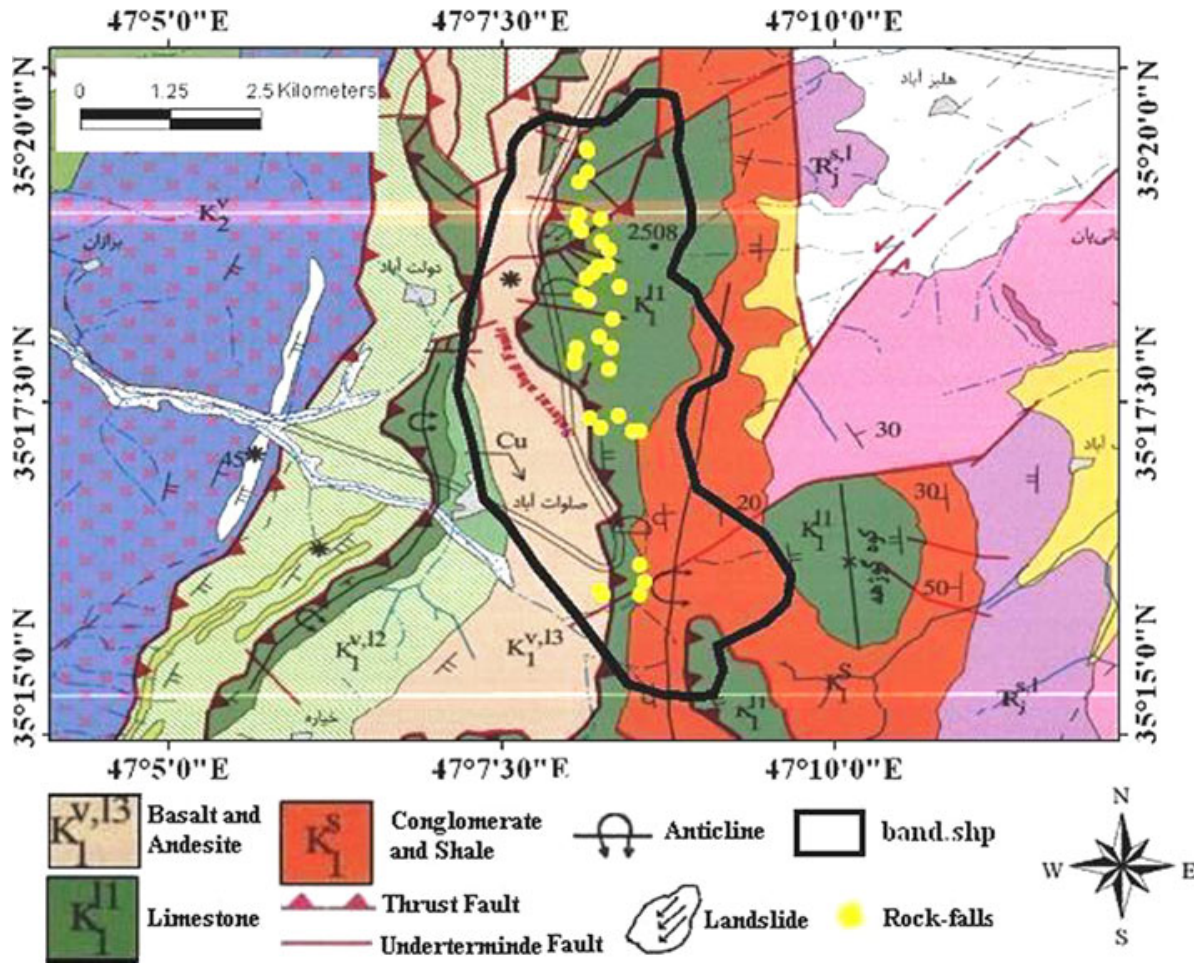

Fig. 3 Geology map of the study area

randomly selected. The data in the report were verified using field surveying and slopes instability observations. The rock-falls that had occurred on the slopes had high-density cracks and joints so that on some of the slopes in the case study area, the dimensions of cracks and joints were comparatively large causing the rocks to fall downward the slope and be collected in its toe (Fig. 1).

The most significant fault in the study area is the Salavat Abad deep active fault. It passes through the entire area from the south to the north. The distances of all rock-falls to the fault section were calculated and classified for the convenience of interpretation. Generally, rock masses near the Salavat Abad fault zone are less intact and severely fractured. According to our investigation, the Salavat Abad deep fault is a dominant factor controlling the development of rock-falls (Fig. 4).

\subsection{Data and methods}

First of all, eight effective factors on rock-falls were recognized based on the field work including social research techniques, that is, local interviews and comprehensive literature reviews. They are as follows: slope degree, slope aspect, slope curvature, elevation, distance to road, distance to fault, lithology, and land use. The dependent variable was the presence of rock-falls at the thirty-four locations used as sites considered as susceptible to rock-fall along the $11 \mathrm{~km}$ of a road in the Salavat Abad saddle. The Sanandaj and Halizabad 1:25,000 topography maps were geo-referenced with the Erdas Imagine 8.5 Software. Contour lines were obtained from the 1:25,000 topographic maps with interval of 
(a)


(b)


Slope aspect class

(c)
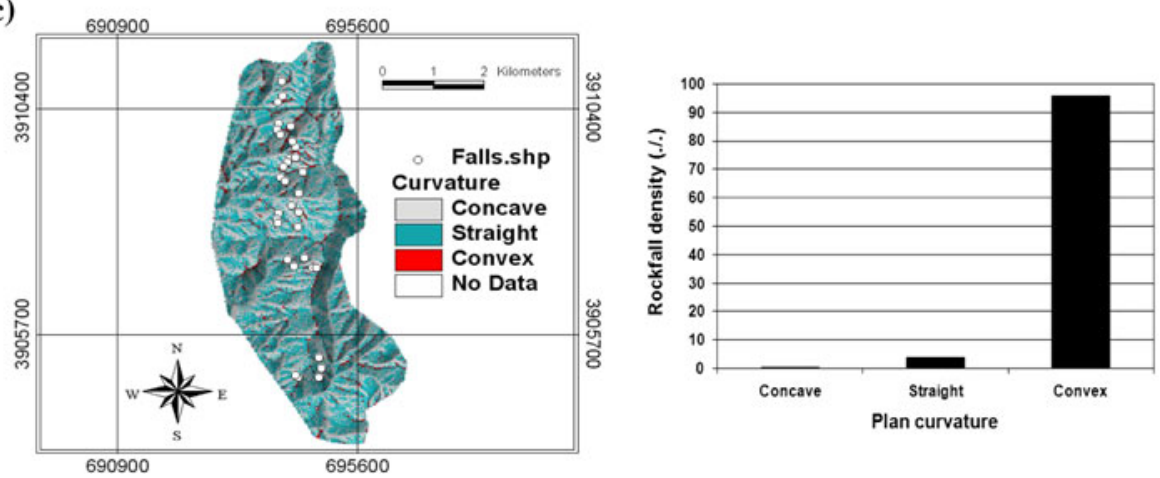

Fig. 4 Independent variables maps and histogram of rock-fall density for each variable including the following: a slope angle, b slope aspect, $\mathbf{c}$ slope curvature, $\mathbf{d}$ elevation above sea level, e distance to road, f distance to fault, $\mathbf{g}$ lithology

$10 \mathrm{~m}$ using the Arc View 3.2 software. The digital elevation model has been produced from the digitized contour lines with $20 \times 20 \mathrm{~m}$ pixel resolution, using a triangular irregular network (TIN) model. Slope degree, slope aspect, slope curvature, and elevation maps were derived from the digital elevation model (DEM). Distance to road and fault were calculated using conventional GIS functions. Lithology map with the same resolution was obtained from a 1:100,000 geology map (Table 1). The 34 rock-fall areas were 
(d)
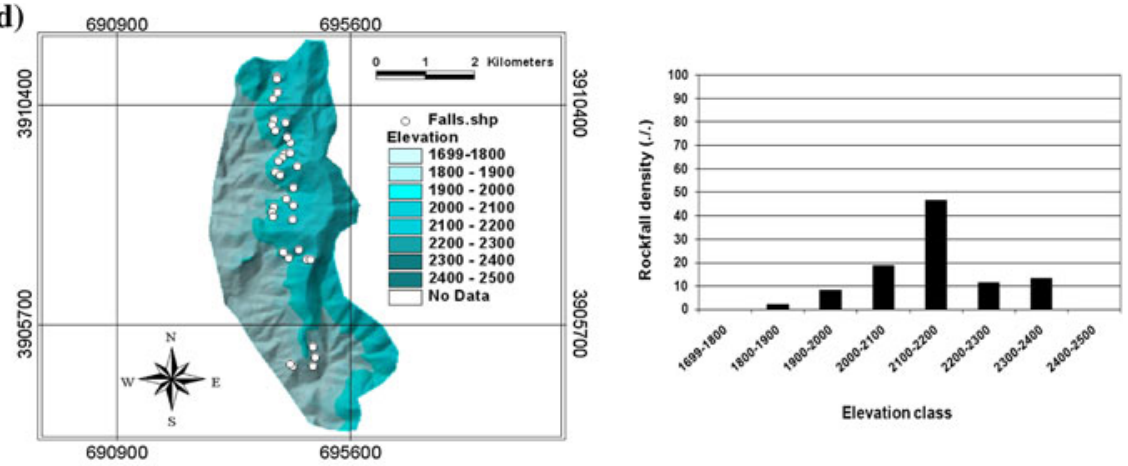

Elevation class

(e)
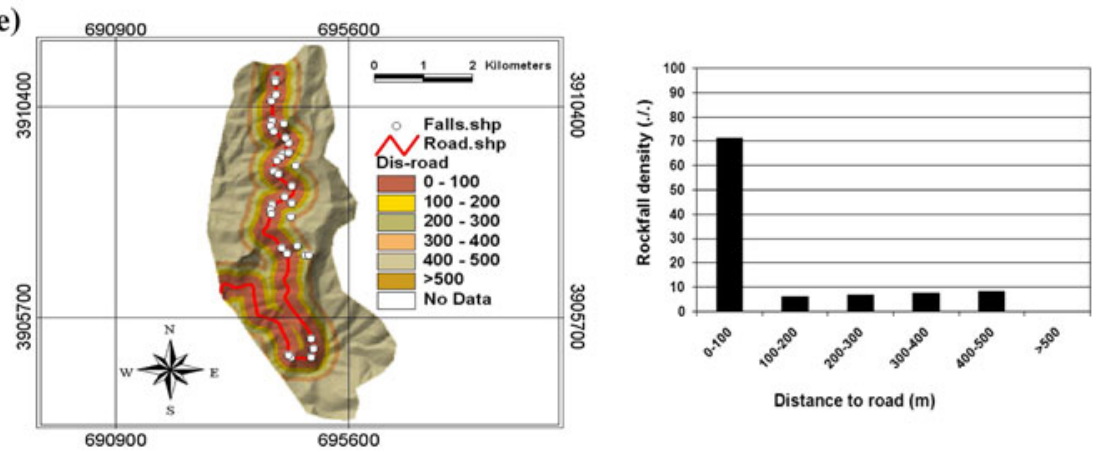

(f)
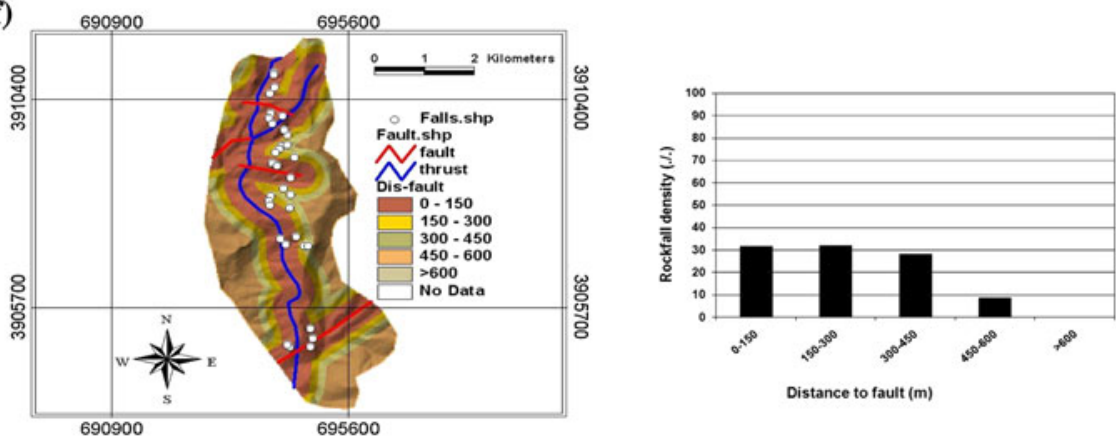

(g)
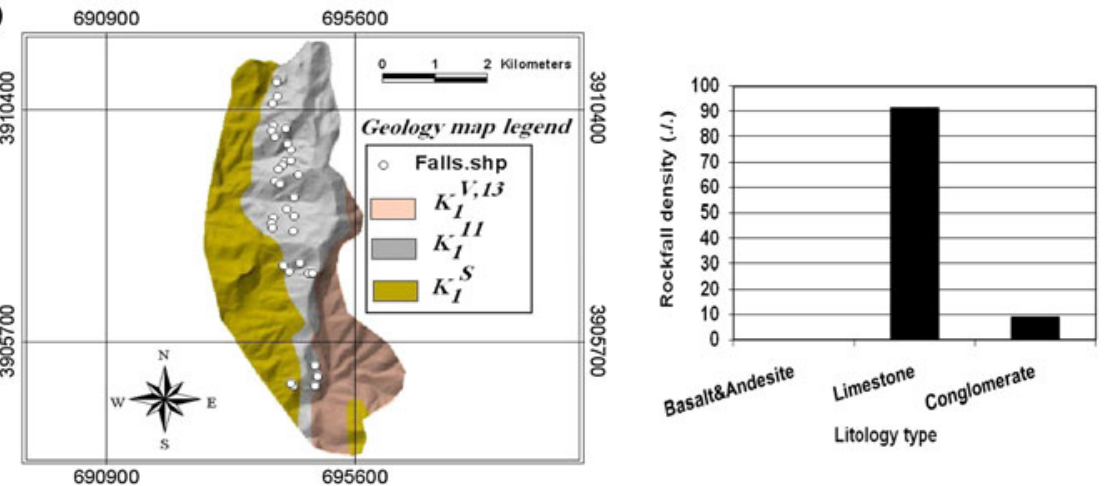
Basaltsandes site Limestone conglomerate Litology type

Fig. 4 continued 
Table 1 Data layer of study area

\begin{tabular}{|c|c|c|c|c|c|}
\hline Classification & $\begin{array}{l}\text { Sub- } \\
\text { classification }\end{array}$ & $\begin{array}{l}\text { Extracted } \\
\text { factor }\end{array}$ & $\begin{array}{l}\text { GIS data } \\
\text { type }\end{array}$ & Scale & References \\
\hline \multirow[t]{7}{*}{ Basic map } & Rock-fall & $\begin{array}{l}\text { Rock-falls } \\
\text { inventory }\end{array}$ & $\begin{array}{l}\text { Point } \\
\text { coverage }\end{array}$ & $1: 25,000$ & Field works \\
\hline & \multirow[t]{3}{*}{ Topography } & Slope gradient & Grid & $20 \mathrm{~m} \times 20 \mathrm{~m}$ & \multirow{3}{*}{$\begin{array}{l}\text { Iran Cartographic } \\
\text { Organization }\end{array}$} \\
\hline & & Slope aspect & Grid & $20 \mathrm{~m} \times 20 \mathrm{~m}$ & \\
\hline & & $\begin{array}{l}\text { Slope } \\
\text { curvature }\end{array}$ & Grid & $20 \mathrm{~m} \times 20 \mathrm{~m}$ & \\
\hline & \multirow[t]{2}{*}{ Geology } & Lithology & $\begin{array}{l}\text { Polygon } \\
\text { coverage }\end{array}$ & $1: 100,000$ & $\begin{array}{c}\text { Iran Geological } \\
\text { Organization }\end{array}$ \\
\hline & & Fault & $\begin{array}{l}\text { Line } \\
\text { coverage }\end{array}$ & & \\
\hline & $\begin{array}{l}\text { Land Sat ETM } \\
\text { image }\end{array}$ & Land use & Grid & $20 \mathrm{~m} \times 20 \mathrm{~m}$ & Iran Space Agency \\
\hline
\end{tabular}

digitized to produce a rock-fall distribution map. In this study, each 20-m pixel represents a rock-fall. As mentioned before, 34 pixels (rock-fall or slope) were selected to establish the relationship between rock-fall presence and the presence of factor. All data layers were rasterized to the DEM resolution using Arc View 3.2. The rock-fall locations that are used in present study were mainly extracted from the Transport Office of the Kurdistan province as well as from past reports and field verification. In this study, we have used a basic data set prepared by the Iran Cartographic Center, the Iran Geological Organization and the Iran Space Agency. The data are of relatively high quality. Table 1 shows some detailed information about the data used.

\subsection{Logistic multiple regression}

Logistic multiple regression is a multivariate technique, which consider several physical parameters that may affect the probability of rock-fall occurrence. The regression is considered here ideal to integrate both the binary and the scalar values as the independent variables, which allows for the use of variables that are not continuous or qualitatively derived. In the present study, the dependent variable is a binary variable representing the presence or absence of rock-falls. The technique of logistic multiple regression yields coefficients for each variable based on data derived from samples taken by the study area. These coefficients serve as weights in an algorithm, which can be used in the GIS database to produce a map depicting the probability of rock-fall occurrence. Quantitatively, the relationship between the occurrence and its dependency on several variables can be expressed as:

$$
P(\text { event })=\frac{1}{\left(1+\exp ^{-z}\right)}
$$

where $p$ (event) is probability of an event occurring. In the present, $p$ (event) is the estimated probability of rock-fall occurrence. As $Z$ varies from $-\infty$ to $+\infty$, the probability varies from 0 to $1 . Z$ is the linear combination:

$$
z=B_{0}+B_{1} X_{1}+B_{2} X_{2}+\cdots+B_{n} X_{n}
$$


General equation:

$$
Y=\log i t(p)=\ln \left(\frac{p}{1-p}\right)=B_{0}+B_{1} X_{1}+B_{2} X_{2}+\cdots+B_{n} X_{n}
$$

where $Y$ is probability of rock-fall occurrence, $B_{n}(i=0,1, \ldots, n)$ is the coefficient estimated from the sample data, $\mathrm{n}$ is the number of independent variables, and $X_{n}$ $(i=0,1, \ldots, n)$ is the independent variables. In logistic multiple regression, a coding scheme should be selected for the categorical variables that by creating a new set of variables that correspond in some way to the original categories. The number of new variables required to present a categorical variables is one less than that of the number of categories. The coefficients of the logistic multiple regression models are estimated using the maximum-likelihood method. In other words, the coefficients that make the observed results most "likely" are selected. Since the relationship between the independent variables and the probability is nonlinear in the logistic multiple regression model, an iterative algorithm is necessary for parameter estimation. Logistic multiple regression modeling is intended to describe the likelihood of rock-fall occurrence on a regional scale and is very suitable for the assessment of slope instability, since the observed data consist of locations (points) or cells with a value of 0 (absence of rock-fall) or 1 (presence of rock-fall). This method allows a spatial distribution of probabilities or susceptibility values to calculate within the GIS environment.

\section{Results}

\subsection{Rock-fall susceptibility modeling}

A multiple logistic regression model was constructed initially based on the physical parameters (Table 2). In the present analysis, the likelihood-ratio test is used for determining whether variables should be added to the model. If the observed significance level is greater than the probability for remaining in the model ( 0.1 in this study), the variable is excluded from the process and the processing statistics are recalculated to see whether any other variables are eligible for excluding. Both slope aspect and land use were found to be not significant and were thus eliminated from the stepwise procedure. Not that all the variables in the analysis are binary variables representing presence or absence of the corresponding mapping units or intervals. For each variable, the last category is used as the default reference category, and coefficient of that map unit or category is thus overridden. Coefficients, significance, and $\operatorname{Exp}(\beta)$ are shown in Table 3. Logistic regression equations, Eq. (4) for the Salavat Abad saddle were obtained:

$$
p(\text { Rockfall-Salvatabad })=\frac{1}{1+\exp ^{-(-2.189-2.705(A 3)+3.135(E 2)-2.832(F 2)+4.976(G 4)-1.672(H 3)}}
$$

For the rock-fall susceptibility map (Fig. 6), in the study area, the values obtained from applying the logistic multiple regressions (Eq. 4) were transferred to the Arc View GIS 3.2 Software system and applied to the independent variables representing the present condition for each pixel or cell within the study area. At last, the range of values of susceptibility to rock-falls in the susceptibility map was classified into 4 categories: very low $(0-0.25)$, low $(0.25-0.35)$, moderate $(0.35-0.5)$, and high $(>0.5)$. The ranges of the 
Table 2 List of independent variables used in logistic regression

\begin{tabular}{|c|c|c|c|c|c|c|c|c|c|}
\hline $\begin{array}{l}\text { Slope } \\
\text { degree }\end{array}$ & Symbol & $\begin{array}{l}\text { Slope } \\
\text { aspect }\end{array}$ & Symbol & \multicolumn{2}{|c|}{ Elevation } & Symbol & \multicolumn{2}{|c|}{ Land use } & Symbol \\
\hline $0-10$ & A1 & Flat & B1 & \multicolumn{2}{|c|}{$1,699-1,800$} & $\mathrm{C} 1$ & \multicolumn{2}{|c|}{ Garden } & D1 \\
\hline $10-15$ & A2 & North & B2 & \multicolumn{2}{|c|}{$1,800-1,900$} & $\mathrm{C} 2$ & \multicolumn{2}{|c|}{ Garden and rang } & D2 \\
\hline $15-20$ & A3 & East north & B3 & \multicolumn{2}{|c|}{$1,900-2,000$} & $\mathrm{C} 3$ & & & D3 \\
\hline $20-25$ & A4 & East & B4 & \multicolumn{2}{|c|}{$2,000-2,100$} & $\mathrm{C} 4$ & \multicolumn{2}{|c|}{ Rocky area } & D4 \\
\hline $25-30$ & A5 & East south & B5 & \multicolumn{2}{|c|}{$2,100-2,200$} & $\mathrm{C} 5$ & \multicolumn{2}{|c|}{ Salavat Abad village } & D5 \\
\hline $30-35$ & A6 & South & B6 & \multicolumn{2}{|c|}{$2,200-2,300$} & C6 & & & \\
\hline $35-40$ & A7 & West south & B7 & \multicolumn{2}{|c|}{$2,300-2,400$} & $\mathrm{C} 7$ & \multicolumn{2}{|c|}{ Semi-density range } & \\
\hline \multirow[t]{2}{*}{$>40$} & A8 & West & B8 & \multicolumn{2}{|c|}{$2,400-2,500$} & $\mathrm{C} 8$ & & & \\
\hline & & West north & B9 & & & & & & \\
\hline \multicolumn{2}{|l|}{ Lithology } & Symbol & $\begin{array}{l}\text { Distance } \\
\text { to road }\end{array}$ & Symbol & \multicolumn{2}{|c|}{$\begin{array}{l}\text { Distance } \\
\text { to fault }\end{array}$} & Symbol & $\begin{array}{l}\text { Slope } \\
\text { curvature }\end{array}$ & Symbol \\
\hline \multirow{2}{*}{\multicolumn{2}{|c|}{ Basalt and andesite }} & E1 & $0-100$ & $\mathrm{~F} 1$ & & $0-150$ & G1 & Concave & H1 \\
\hline & & $\mathrm{E} 2$ & $100-200$ & $\mathrm{~F} 2$ & & ;0-300 & G2 & Straight (flat) & $\mathrm{H} 2$ \\
\hline \multicolumn{2}{|l|}{ Limestone } & E3 & $200-300$ & $\mathrm{~F} 3$ & & $0-450$ & G3 & & H3 \\
\hline \multirow{3}{*}{\multicolumn{2}{|c|}{ Conglomerate and shale }} & & $300-400$ & $\mathrm{~F} 4$ & & $0-600$ & G4 & Convex & \\
\hline & & & $400-500$ & F5 & $>60$ & & G5 & & \\
\hline & & & $>500$ & F6 & & & & & \\
\hline
\end{tabular}

individual categories were derived based on histogram of the estimated susceptibility to rock-fall shown in Fig. 5 (Dai and Lee 2002). At first, the rock-fall susceptibility map was divided into 10 categories. This map was then overlaid with presence and absence of rockfalls, and this histogram was obtained. Two categories from 0 to 0.5 (left side as low susceptibility) and from 0.5 to 1 (right side as high susceptibility) are shown. The left side was divided into three categories based on absence of rock-falls, and the right left was divided into one category. Finally, the susceptibility map was classified into 4 categories: very low (0-0.25), low (0.25-0.35), moderate $(0.35-0.5)$, and high $(>0.5)$. The rock-fall susceptibility map was divided into 10 categories. Theoretically, if we have a model that successfully distinguishes the two groups based on a classification cutoff value of 0.5 , the cases for which rock-falls have occurred should be to the right of 0.5 , while the cases for which rock-falls have not occurred should be to the left of 0.5 .

\subsection{Susceptibility map and its reliability}

The actual calculation was done using the "Map Calculator" and "Map Query" functions in Arc/view 3.2. The $\beta$ coefficients had been obtained from the statistical analysis. Then, $\beta$ values were assigned to each category of variable (Table 3). After assignment of $\beta$ value to each category, we can combine all layers (Fig. 4) by using Eqs. (1) and (2) to yield the susceptibility map (Fig. 6). The fitted logistic regression model can be used to calculate the probability of rock-fall occurrence of both the rock-fall and the non-rock-fall. Whenever the probability of a rock-fall is larger than 0.5 , the rock-fall is considered likely; and whenever the probability of a rock-fall is less than 0.5 , that rock-fall is considered unlikely. Thus, when the probability in (1) for the any of original rock-fall is larger than 0.5 , the prediction is considered acceptable. Similarly, if $p<0.5$ for the case of non-rock-fall, the 
Table 3 The coefficients, significance, and $\operatorname{Exp}(\beta)$ for logistic regression in this study

\begin{tabular}{llclr}
\hline Independent parameter & Class & Coefficient & Significant & Exp $(\beta)$ \\
\hline Slope angle & $15-20^{\circ}$ & -2.705 & 0.033 & 0.067 \\
Geology & Limestone & 3.135 & 0.000 & 22.978 \\
Distance to road & $100-200 \mathrm{~m}$ & -2.832 & 0.027 & 0.059 \\
Distance to fault & $450-600 \mathrm{~m}$ & 4.976 & 0.011 & 144.825 \\
Slope curvature & Convex & -1.672 & 0.025 & 0.188 \\
Constant & & -2.189 & 0.005 & 0.112 \\
\hline
\end{tabular}

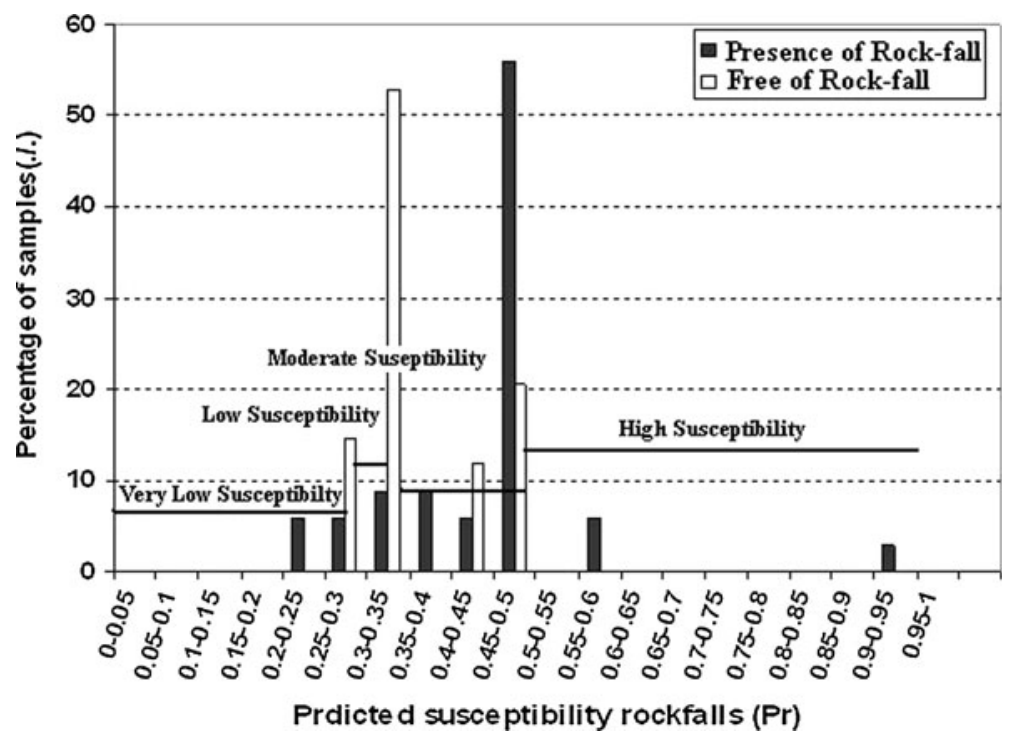

Fig. 5 Histogram of the predicted rock-fall susceptibility for the samples used in this study

prediction is viewed as successful. In validation, the accurate rate is $85.3 \%$ for rock-fall group and $75.1 \%$ for non-rock-fall group using error matrix method. The total accurate rate is $79.1 \%$, which is considered acceptable (Table 4).

In the other method, we have conducted another series of logistic regression analysis by excluding each of the categories of slope degree, slope aspect, slope curvature, elevation, distance to road, distance to fault, lithology, and land use. This is a standard technique in logistic regression analysis to examine the statistical significance of each of the selected independent variables (e.g., Hosmer and Lemeshow 2000; Menard 2002). It was found that $-2 \mathrm{LL}$ is the smallest if all variables are included. The $-2 \mathrm{LL}$ can be considered as a goodness of fit for the model. Since the likelihood is between 0 and $1, \log$ likelihood ranges from negative infinity to zero, and in turn, the $-2 \mathrm{LL}$ would be from 0 to infinity. Therefore, the original analysis of incorporating all variables should be used. Table 5 has shown that $-2 \mathrm{LL}$ for all eight variables is 57.445 , and for slope aspect, elevation and land use, this value is the same. In other words, these three variables are not significant at $99 \%$ level of probability with rock-falls and excluded from the final model. However, there is no universal standard for this parameter to be used for validity check. Another approach is to 


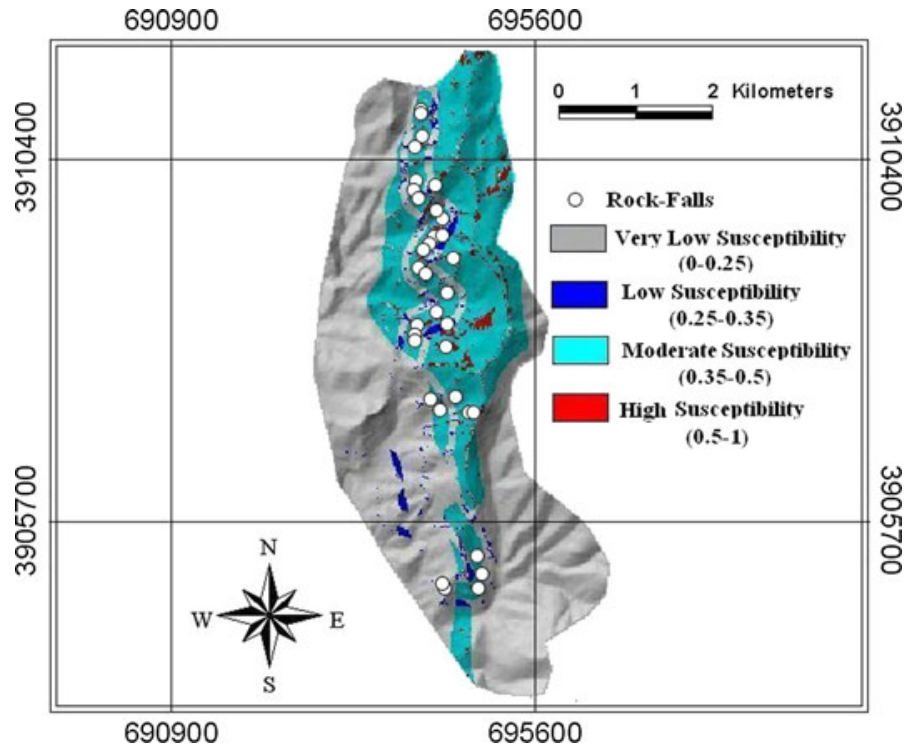

Fig. 6 Rock-fall susceptibility map of the Salavat Abad saddle

Table 4 Classification table and predicted percentage correct test

\begin{tabular}{llll}
\hline & \multicolumn{2}{l}{ Predicted } & Correction percentage (\%) \\
\cline { 2 - 4 } & Absence of rock-fall (0) & Presence of rock-fall (1) & \\
\hline Absence of rock-fall (0) & 24 & 10 & 70.6 \\
Presence of rock-fall (1) & 5 & 29 & 85.3 \\
& & & 77.9 \\
\hline
\end{tabular}

use the coefficient of correlation. Similar to the $R^{2}$ in linear regression, there are also correlation coefficients for logistic regression analysis and they are called Cox and Snell $R^{2}$ (e.g., Cox and Snell 1989) and Nagelkerke $R^{2}$ (e.g., Nagelkerk 1991). For the present model, they are 0.418 and 0.558 , respectively (Table 5). The theoretical values of these coefficients are again from 0 to 1 . Unlike the linear regression, these coefficients can be relatively small (this does not necessarily invalidate the model in the case of logistic regression) and there is again no universal standard of what value of Cox and Snell $R^{2}$ and Nagelkerke $R^{2}$ should be obtained in the regression to be acceptable, that $R^{2}>0.9$ is normally considered as a good indicator of a reasonable fit.

For validation of rock-fall susceptibility calculation models, two basic assumptions are needed. Firstly, rock-falls are related to spatial information such as topography, geology, road, and fault, and secondly, future rock-falls will be precipitated by a specific impact factor such as earthquake. In this study, the two assumptions are satisfied because the rockfalls were related to the spatial information, and the rock-falls were precipitated by one road and fault in the study area. Also, the susceptibility map was verified using existing rock-fall location. For this, the logistic regression analysis result in modeling rock-fall susceptibility in the study area was evaluated by calculating the success curve rate (SCR) and the percentage of known rock-falls in the various susceptibility categories. For the 
Table 5 Some statistics and map accuracy evaluation

\begin{tabular}{lllll}
\hline Independent variable & $-2 \log$ likelihood $(-2 \mathrm{LL})$ & Cox and Snell $R^{2}$ & Nagelkerke $R^{2}$ & (AUC \%) \\
\hline All variables & 57.445 & 0.418 & 0.558 & 77.57 \\
Without slope degree & 59.904 & 0.397 & 0.529 & 71.80 \\
Without slope curvature & 62.985 & 0.396 & 0.492 & 73.97 \\
Without elevation & 57.445 & 0.418 & 0.558 & 73.11 \\
Without distance to road & 72.230 & 0.277 & 0.369 & 66.17 \\
Without distance to fault & 72.390 & 0.275 & 0.367 & 70.24 \\
Without lithology & 62.167 & 0.376 & 0.502 & 72.93 \\
\hline
\end{tabular}

verification by the SCR method, the area under the SCR curve (AUC) model was used (e.g., Lee and Sambath 2006; Lee and Pradhan 2006; Oh et al. 2009; Pradhan and Lee 2009, 2010; Nandi and Shakoor 2009; Pradhan 2010; Oh and Lee 2011). To obtain the SCR, the calculated rock-fall susceptibility index values of all pixels in the study area were ranked in a descending order. Then, the ranked pixel values were divided into 100 classes with accumulated $1 \%$ equal area intervals. The rate curves explain how well the method and factors classify rock-falls. The area under the curve (AUC) can be used to assess the prediction of the model. Total area $=1$ denotes perfect prediction accuracy. The rate verification results appear as graph in Fig. 7. For the case of this study, the area under the curve was 0.7757 and the prediction accuracy was $77.57 \%$ (Table 5; Fig. 7). For example, in the case of our application to the study area, the 90-100\% class with the highest $10 \%$ of probability of a rock-fall contains $15 \%$ of the rock-falls in that area. The $80-100 \%$ class with the highest $20 \%$ of probability of a rock-fall contains $53 \%$ of the rock-falls in the area. The $70-100 \%$ class with the highest $30 \%$ of probability of a rock-fall contains $71 \%$ of the rock-falls in that area (Fig. 7).

In addition to success rate and AUC to investigate the reliability of the hazard analysis, another way is to consider the ratio of the rock-fall location points versus the rock-fall susceptibility. Lee and Min (2001) suggested and used this method for landslide

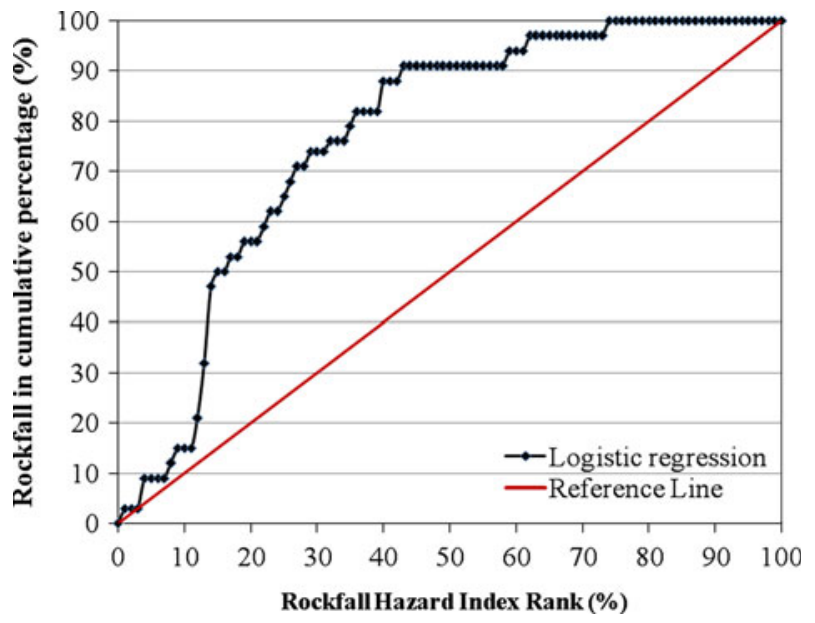

Fig. 7 Cumulative frequency diagram showing rock-fall susceptibility index rank occurring in cumulative percent of rock-fall occurrence (AUC $=77.57 \%$ ) 
Table 6 Comparison of rock-fall occurrence and rock-fall susceptibility map using logistic regression method for the case study

\begin{tabular}{|c|c|c|c|c|c|c|}
\hline $\begin{array}{l}\text { Range of } \\
\text { susceptibility } \\
\text { map }\end{array}$ & $\begin{array}{l}\text { Average of } \\
\text { susceptibility } \\
\text { map }\end{array}$ & $\begin{array}{l}\text { Number } \\
\text { of pixels }\end{array}$ & $\begin{array}{l}\text { Percentage of } \\
\text { pixels }(a, \%)\end{array}$ & $\begin{array}{l}\text { Number of } \\
\text { rock-falls }\end{array}$ & $\begin{array}{l}\text { Percentage of } \\
\text { rock-falls }(b, \%)\end{array}$ & $\mathrm{b} / \mathrm{a}$ \\
\hline $0-0.228$ & 0.266 & 15,782 & 33.74 & 4 & 11.764 & 0.348 \\
\hline $0.228-0.380$ & 0.341 & 15,021 & 32.11 & 3 & 8.823 & 0.274 \\
\hline $0.380-0.458$ & 0.419 & 4,247 & 9.08 & 3 & 8.823 & 0.971 \\
\hline $0.458-0.535$ & 0.496 & 10,563 & 22.58 & 21 & 61.764 & 2.73 \\
\hline $0.535-0.613$ & 0.574 & 671 & 1.43 & 2 & 5.882 & 4.11 \\
\hline $0.613-0.690$ & - & - & - & - & - & - \\
\hline $0.690-0.768$ & - & - & - & - & - & - \\
\hline $0.768-0.845$ & - & - & - & - & - & - \\
\hline $0.845-0.923$ & - & - & - & - & - & - \\
\hline $0.923-1$ & 0.961 & 497 & 1.06 & 1 & 2.944 & 2.77 \\
\hline Sum & & 46,781 & 100 & 34 & 100 & \\
\hline
\end{tabular}

susceptibility (e.g., Chau and Chan 2005). At this way, rock-fall probability should first be divided into intervals such that within each of them the amount of coverage area is about the same (Table 6). As shown in Table 6, the susceptibility and probability of larger than 0.5 roughly corresponds to b/a $>1$. For example; in the first, second, and third class of the susceptibility and probability less than 0.5 , the amount of $\mathrm{b} / \mathrm{a}<1$, and for the other classes, the susceptibility and probability more than 0.5 , the amount of $b / a>1$, which indicates that the present logistic regression provides a reliable hazard or susceptibility map for the case study.

The accuracy of the rock-fall susceptibility map provided by the model is further checked by calculating Seed Cell Area Index (SCAI), which was suggested by Suzen and Doyuran (e.g., Suzen and Doyuran 2004a, b) as follows:

$$
\text { SCAI }=\frac{\text { Area extent of susceptibility class }(\%)}{\text { rockfall in each susceptibility class (\%) }}
$$

The SCAI lies in the correct classification of seed cells within a very conservative areal extent, and it is expected that the high and very high susceptibility classes should have very small SCAI values, and that low and very low susceptibility classes should have much higher SCAI values (e.g., Aykut and Necdet 2011). The resulting values are the SCAI densities of rock-fall among the class that are shown in Table 7.

\section{Discussion and conclusion}

The aim of this study was to assess efficiency of logistic regression model for rock-fall susceptibility mapping along a mountainous road in the Kurdistan province, Iran. Rockfalls are natural phenomena that often have detrimental consequences. In susceptibility management, rock-fall susceptibility map can help to effectively prevent and manage susceptibility. Many qualitative and quantitative techniques are useful for analyzing the relationship between rock-falls and their affective parameters. In this research, we attempted to provide rock-fall susceptibility maps using the relationship between rock-fall 
Table 7 Rock-fall distribution in predicted rock-fall susceptible zone

\begin{tabular}{llll}
\hline $\begin{array}{l}\text { Rock-fall } \\
\text { susceptible } \\
\text { zone }\end{array}$ & $\begin{array}{l}\text { \%Area of } \\
\text { predicted } \\
\text { zone }\end{array}$ & $\begin{array}{l}\text { \%Area of } \\
\text { observed rock-fall } \\
\text { per class }\end{array}$ & $\begin{array}{l}\text { SCAI } \\
\text { (rock-fall } \\
\text { density) }\end{array}$ \\
\hline Very low & 42.12 & 14.72 & 2.8614 \\
Low & 13.21 & 8.82 & 1.4977 \\
Moderate & 38.15 & 64.67 & 0.5899 \\
High & 6.52 & 11.79 & 0.5530 \\
\hline
\end{tabular}

locations and determining parameters. The logistic regression model was applied to study the impact of different parameters on rock-fall and susceptibility map of the area. The first results of the logistic regression were the model statistics and coefficients, which were useful to assess the accuracy of the regression function and the role of parameters on the presence or absence of landslides. The forward condition stepwise method was applied for statistical analyses. Slope aspect, land use, and elevation were considered to be not significant for predicting rock-fall and were excluded from the final model. For the study area, in particular, the most important effective factor is $450-600 \mathrm{~m}$ distance to fault with coefficient of 4.976 and 0.011. $p$ Value for significance and $\operatorname{Exp}(\beta)$ equal to 144.825 , which means that if distance to fault increases by one unit, the value for rock-fall occurrence will increase 144.825 in time. Other factors are geology (limestone), slope curvature (convex), slope angle $\left(15-20^{\circ}\right)$, and distance to road (100-200 m), respectively. Distance to fault and geology by having positive coefficient and high value for $\operatorname{Exp}(\beta)$ has more influence than other factors. The results of logistic regression model were validated using some kinds of validation strategies and were accepted. The results are in line with those of Chau et al. (2004) and Chau and Chan (2005) in their study. Considering coefficients estimated for the logistic regression (Table 3), the "closeness to roads" parameter was found to have the strongest relationship with rock-fall occurrence. Ayalew et al. (2005) have introduced "proximity to roads" parameter as the most important factor on landslide occurrence in Kakuda-Yahico, central Japan. They declared that most of the landslides located in the range 0-100 m from roads. Also, Lee and Sambath (2006), Greco et al. (2007) and Kelarestaghi and Ahmadi (2009) have emphasized adverse effect of road construction on landslide occurrence in their studies. Table 2 indicates that geological units belonging to the Cretaceous era and consisting mostly of limestone are more susceptible to rock-fall. Can et al. (2005) and Nefeslioglu et al. (2008) emphasized causative role of geological units on mass movements in their researches. Land use was excluded from the logistic regression model runs because land use units do not show much change in the study area and most of the rock-falls have occurred in rocky areas. In the Salavat Abad saddle, the Salavat Abad fault by a thrust mechanism led to the generation of joints and cracks of different sizes so that by continued physical weathering and thawing, they have caused rock-falls due to gravity toward the toe of the slope. The road in the region has been encompassed by this fault spiral form, and most of the rock-falls have occurred around it. Therefore, the presence of the fault is one of the most important effective factors for rockfalls occurrence in the study area. The removal of the slope aspect from the logistic regression model run is caused by the presence of the Salavat Abad fault. The role of the Salavat Abad fault was very predominating so that slope aspect did not show any statistical relationship with rock-falls: some of the rock-falls occurred on the west slope instead of on the east slope. The rock-fall susceptibility map was classified into four categories as follows: very low, low, moderate, and high. The rock-fall susceptibility map was assessed 
using the area under the curve (AUC) in ROC value (Fig. 7). This diagram shows the $77.57 \%$ as the value of the area under the curve (AUC), which indicates that in the study area; the rock-fall susceptibility map is highly accurate.

To quantitatively compare the result, the areas under the curves (AUC) were individually recalculated for all factors. The results showed that with all effective factors in the logistic regression model, the AUC value rises to $77.57 \%$, and the values obtained for the other variables are as follows: $71.80 \%$, slope aspect, $73.97 \%$, slope curvature, $73.11 \%$, elevation above the sea level, $66.17 \%$, geology, $70.24 \%$, distance to road, and $72.93 \%$, distance to fault. So, all variables in the rock-fall susceptibility map appear effective, and the prediction of the susceptibility map was measured in this way. These results are in agreement with the results of Lee and Sambath (2006), Lee and Pradhan (2006, 2007), Oh et al. (2009), Jadda et al. (2009), Nandi and Shakoor (2009), Oh et al. (2009), Pradhan (2010), Pradhan and Lee (2010), Chauchan et al. (2010) and Oh and Pradhan (2011) to apply the success rate curve and AUC to investigate the reliability of the landslides susceptibility map. We have also found that $14.72,8.82,64.67$, and $11.79 \%$ of the area is located at very low, low, moderate, and high susceptible zones, respectively.

Table 6 indicates that rock-fall susceptibility and probability has good accordance with rock-falls because in the classes with the susceptibility and probability less than 0.5 , the amount of $\mathrm{b} / \mathrm{a}<1$, and in the classes with the susceptibility and probability more than 0.5 , the amount of $b / a>1$. This result is in line with the result of Chau and Chan in evaluating landslide susceptibility map using logistic regression.

The SCAI values given in Table 7 show that the map generated is adequate because the high and moderate susceptibility classes have very low SCAI values, whereas the SCAI values of the very low and low susceptibility classes are very high (Table 7).

In general, in the study area, in addition to natural parameters including "slope gradient," "slope curvature," "geology," and "closeness to fault," human activities have played a major role on rock-falls. The susceptibility map produced is here considered as acceptable as a basis for studies on mass movement risk management in the study area. If the susceptibility map was overlaid with a vulnerability map (an inventory of building, infrastructure, and other elements at risk and of their expected losses), an objective risk assessment could be achieved. The information derived from this map can help citizens, planners, and engineers to reduce losses caused by existing and future rock-falls by means of prevention and mitigation.

Acknowledgments We wish to thank Prof. Yamagishi Hiromitsu, Ehime University, Japan and Prof. Kam Tim Chau, the Hong Kong Polytechnic University of China, for their advices and suggestions on an earlier version of this manuscript. The authors also wish to thank the Transport Office of the Kurdistan province for the report of rock-falls location in the study area, and the University of Kurdistan, and the University of Mazandaran for their financial supports.

Open Access This article is distributed under the terms of the Creative Commons Attribution License which permits any use, distribution, and reproduction in any medium, provided the original author(s) and the source are credited.

\section{References}

Akgun A, Bulut F (2007) GIS-based landslide susceptibility for Arsin-Yomra (Trabzon, North Turkey) region. Environ Geol 51:1377-1387

Akgun A, Dag S, Bulut F (2008) Landslide susceptibility mapping for a landslide prone area (Findikli, NE of Turkey) by likelihood-frequency ratio and weighted linear combination models. Environ Geol 54:1127-1143 
Ayalew L, Yamagishi H (2004) The application of GIS-based logistic regression for landslide susceptibility mapping in the Kakud-Yahiko Mountains, Central Japan. Geomorphology 65:15-31

Ayalew L, Yamagishi H, Marui H, Kanno T (2005) Landslides in Sado Island of Japan: Part II. GIS-based susceptibility mapping with comparisons of results from two methods and verifications. Eng Geol $81: 432-445$

Ayenew T, Barbieri G (2005) Inventory of rock-fall and susceptibility mapping in the Dessie area, northern Ethiopia. Eng Geol 77:1-15

Aykut A, Necdet T (2011) Mapping erosion susceptibility by a multivariate statistical method: a case study from the Ayvalık region, NW Turkey. Comput Geosci 37:1515-1524

Azzoni A, Barbera GL, Zaninetti A (1995) Analysis and prediction of rock-falls using a mathematical model. J Rock Mech Min Sci Geomech Abst 32:709-724

Baeza C, Corominas J (2001) Assessment of shallow landslide susceptibility by means of multivariate statistical techniques. Earth Surf Proc Land 26:1251-1263

Barredol JI, Benavidesz A, Herhl J, Van Westen CJ (2000) Comparing heuristic landslide susceptibility assessment techniques using GIS in the Tirajana basin, Gran Canaria Island, Spain. J Appl Earth Observ Geoinf 2:9-23

Can T, Nefeslioglu HA, Gokceoglu C, Sonmez H, Duman Y (2005) Susceptibility assessments of shallow earth flows triggered by heavy rainfall at three catchments by logistic regression analysis. Geomorphology 82:250-271

Carrara A, Cardinali M, Guzzetti F (1992) Uncertainty in assessing landslide susceptibility and risk. J Interdenominat Theol Center (ITC) 2:172-183

Carrara A, Cardinali M, Guzzetti F, Reichenbach P (1995) GIS technology in mapping landslide susceptibility. In: Carrara A, Guzzetti F (eds) Geographical information systems in assessing natural hazards. Kluwer, Dordrecht, pp 135-175

Chau KT, Chan JE (2005) Regional bias of landslide data in generating susceptibility maps using logistic regression for Hong Kong Island. J Rock Mech Rock Eng 2(4):280-290

Chau KT, Wong RHC, Lin J, Lee CF (2003) Rock-fall susceptibility analysis for Hong Kong based on Rock-fall Inventory. J Rock Mech Rock Eng 36(5):383-408

Chau KT, Tang YF, Wong RHC (2004) GIS-Based Rock-fall susceptibility map for Hong Kong. J Rock Mech Min Sci 41(3):530-542

Chauchan Sh, Sharma M, Arora MK, Gupta NK (2010) Landslide susceptibility zonation through rating derived from artificial neural network. J Appl Erath Observ Geoinf 12:340-350

Choi J, Oh HJ, Lee HJ, Lee Ch, Lee S (2012) Combining landslide susceptibility maps obtained from frequency ratio, logistic regression, and artificial neural network models using ASTER images and GIS. Eng Geol 124:12-23

Chung CF, Fabbri AG (2003) Validation of spatial prediction models for landslide hazard mapping. Nat Hazards 30:451-472

Chung CF, Fabbri AG, Van Westen CJ (1995) Multivariate regression analysis for landslide susceptibility zonation. In: Carrara A, Guzzetti F (eds) Geographical information systems in assessing natural hazards. Kluwer, Dordrecht, pp 107-133

Corominas J, Santacana N (2003) Stability analysis of the Vallcebre translational slide Eastern Pyrenees (Spain) by means of a GIS. Nat Hazard 30(3):473-485

Cox DR, Snell EJ (1989) Analysis of binary data, 2nd edn. Chapman and Hall, London

Dai FC, Lee CF (2002) Landslide characteristics and slope instability modeling using GIS, Lantau Island, Hong Kong. Geomorphology 42:213-228

Evans SG, Hungr O (1993) The assessment of rock-fall hazard at the base of talus slopes. Can Geotech J 30:620-636

Gorseveski PV, Gessler P, Foltz RB (2000) Spatial prediction of Landslide susceptibility using logistic regression and GIS. In: 4th International conference on integrating GIS and environmental modeling, Alberta, 9 pp

Greco R, Sorriso-Valvo M, Catalano E (2007) Logistic regression analysis in the evaluation of mass movement's susceptibility case study: Calabria, Italy. Eng Geol 89:47-66

Guzzetti F, Carrara A, Cardinali M, Reichenbach P (1999) Rock-fall susceptibility evaluation: a review of current techniques and their application in a multi-scale study, Central Italy. Geomorphology 31:181-216

Hegg C, Kienholz H (1995) Determining paths of gravity-driven slope processes - the 'Vector Tree Model'. In: Carrara A, Guzetti F (eds) Geographic information systems in assessing natural hazards. Kluwer Academic Publishers, Dordrecht, pp 79-92

Hoek E, Bray W (1981) Rock slope engineering (3rd edn) Institution of Mining and Metallurgy, London. 527 pp. International Society for Rocks Mechanics. 1978. Suggested methods for the quantitative description of discontinuities in rock masses. J Rock Mech Min 15:319-368 
Hosmer DW, Lemeshow S (2000) Applied logistic regression, 2nd edn. Wiley, New York

Hungr O, Evans SG (1988) Engineering evaluation of fragmental rock-fall hazards. Proceedings of the 5th international symposium on landslides in Lausanne, Balkema, Rotterdam, pp 685-690

Jadda M, Shafri HZM, Mansor ShB, Sharifikia M, Pirasteh S (2009) Landslide susceptibility evaluation and factor effect analysis using probabilistic-frequency ratio model. Eur J Sci Res 33(4):654-668

Kelarestaghi A, Ahmadi H (2009) Landslide susceptibility analysis with a bivariate approach and GIS in northern Iran. Arab J Geosci 2:95-101

Keylock C, Domaas U (1999) Evaluation of topographic models of rock-fall travel distance for use in hazard applications. Artic Antarctic Alp Res 31(3):312-320

Kirkby MJ, Statham I (1975) Surface stone movement and scree formation. J Geol 83:349-362

Kobayashi Y, Harp EL, Kagawa T (1990) Simulation of rock-falls triggered by earthquakes. J Rock Mech Rock Eng 23:1-20

Lamelas MT, Marinoni O, Hoppe A, Riva J (2008) Doline probability map using logistic regression and GIS technology in the central Ebro Basin (Spain). Environ Geol 54:963-977

Lee S, Min K (2001) Statistical analysis of Landslide susceptibility at Yongin, Korea. Environ Geol 40:1095-1113

Lee S, Pradhan B (2006) Probabilistic landslide susceptibility s and risk mapping on Penang Island, Malaysia. J Earth Syst Sci 115(6):661-672

Lee S, Sambath T (2006) Landslide susceptibility mapping in the Damrei Romel area, Cambodia using frequency ratio and logistic regression models. Environ Geol 50:847-855

Menard SW (2002) Applied logistic regression analysis, 2nd edn. Sage, Thousand Oaks, 111 pp. Network model. Environmental Earth Sciences. doi:10.1007/s12665-009-0245-8 (on-line first)

Nagelkerk E (1991) A note on a general definition of the coefficient of determination. Biomelrika 78(3):691-692

Nandi A, Shakoor A (2009) A GIS-based landslide susceptibility evaluation using bivariate and multivariate statistical analyses. Eng Geol 110:11-20

Nefeslioglu HA, Gokceoglu C, Sonmez H (2008) An assessment on the use of logistic regression and artificial neural networks with different sampling strategies for the preparation of landslide susceptibility maps. Eng Geol 97:171-191

Oh HJ, Lee S (2011) Landslide susceptibility mapping on Panaon Island, Philippines using a geographic information system. Environ Earth Sci 62:935-951

Oh HJ, Pradhan B (2011) Application of a neuro-fuzzy model to landslide-susceptibility mapping for shallow landslides in a tropical hilly area. Comput Geosci 37(9):1264-1276

Oh HJ, Lee S, Chotikasathien W, Kim CH, Kwon JH (2009) Predictive landslide susceptibility mapping using spatial information in the Pechabun area of Thailand. Environ Geol 57:641-651

Pfeiffer TJ, BowenTD (1989) Computer simulation of rock-falls. Bull Assoc Eng Geol 26(1):135-146

Pradhan B (2010) Remote sensing and GIS-based landslide susceptibility analysis and cross-validation using multivariate logistic regression model on three test areas in Malaysia. Adv Space Res 45:1244-1256

Pradhan B, Lee S (2009) Landslide risk analysis using artificial neural network model focusing on different training sites. Int J Phys Sci 3(11):1-15

Pradhan B, Lee S (2010) Landslide susceptibility assessment and factor effect: back-propagation artificial neural networks and their comparison with frequency ratio and bivariate logistic regression modeling. Environ Model Softw 25:747-759

Reger JP (1979) Discriminate analysis as a possible tool in landslide investigations. Earth Surf Proc Land 4:267-273

Sassa K, Wang G, Fukuoka H, Wang F, Ochiai T, Sugiyama M, Sekiguchi T (2004) Landslide risk evaluation and susceptibility zoning for rapid and long-travel rock-fall in urban development areas. Landslides 1(3):221-235

Selby MJ (1982) Hill slope Material and process. Oxford university press, Oxford

Statham I (1976) A scree slope rock-fall model. Earth Surf Process 1:43-62

Su F, Cui P (2010) Susceptibility assessment of landslides caused by the wenchuan earthquake using a logistic regression model. J Mt Sci 7:234-245

Suzen ML, Doyuran V (2004a) HA comparison of the GIS based landslide susceptibility assessment methods: multivariate versus bivariate. Environ Geol 45:665-679

Suzen ML, Doyuran V (2004b) Data driven bivariate landslide susceptibility assessment using geographical information systems: a method and application to Asarsuyu catchment, Turkey. Eng Geol 71:303-352

Wu SS (1985) Rock fall evaluation by computer simulation. Transp Res Rec 1031:1-5

Yamagishi H (2000) Recent rock-fall in western Hokkaido, Japan. Pure Appl Geophys 157:1115-1134 